Литвиненко Світлана

доктор педагогічних наук, професор, професор кафедри практичної психології і психотерапії Рівненського державного гуманітарного університету http://orcid.org/ 0000-0002-7736-2152

Ямницький Вадим

доктор психологічних наук, професор, професор кафедри практичної психології і психотерапії Рівненського державного гуманітарного університету http://orcid.org/0000-0002-1741-1303 DOI https://doi.org/10.35619/prap_rv.vi14.161

\title{
СТАНОВЛЕННЯ ІГРОВОЇ ТЕРАПІЇ В ПСИХОАНАЛІТИЧНИХ ШКОЛАХ А. ФРЕЙД ТА М. КЛЯЙН
}

Анотація. У статті здійснено дослідження особливостей зародження ігрової терапії в дитячому психоаналізі в традиціях шкіл М. Кляйн та А. Фрейд. Незважаючи на те, щзо обидва підходи трунтувалися на принципах $i$ засадах психоаналізу, доробки Кляйн $i$ Фрейд започаткували дві самостійні психоаналітичні школи в галузі дитячої психотерапї та різні позиції щзодо розуміння гри та ї̈ використання в дитячій психотерапії. Згідно підходу Фрейд, у дитячому психоаналізі надавали перевагу роботі з невротичними дітьми, однак Кляйн довела ефективність «ігрового аналізу» в роботі з будь-якими порушеннями і розладами дітей.

Емпіричним матеріалом виступили результати історико-психологічних досліджень процесу становлення й розвитку психоаналітичних знань про дитину та теорію і практику дитячого психоаналізу в першій половині XX століття. Досліджено, щуо в першій половині XX століття теорія $і$ техніка дитячого психоаналізу перебували на стадї розробки, а тому дослідники розвивали уявлення про психоаналітичну роботу з дітьми на основі власних спостережень та експериментів.

3'ясовано, що започаткування ігротерапії відбулося у 20-ті роки XX cm. у теоретичних пошуках та практиці роботи психоаналітиків (Хуг-Хельмут, Кляйн, Фрейд та ін.). Концептуальне обтрунтування теорії і практики дитячого психоаналізу було здійснено школами Фрейд і.Кляйн в період між Першою $і$ Другою світовими війнами. Хоча обидві дослідниці використовували гру в роботі з дітьми, однак вони перебували в постійній полемічі через розбіжності з питань дитячого аналізу та ігрових технік роботи.

Встановлено, що в дитячому психоаналізі гра розглядалася як природна діяльність дітей, що надавала можливості вираження, демонстрації та випробовування в символічній формі за допомогою іграшок, ігрових дій і ролей несвідомих бажань $і$ фантазій, а також особливостей об'єктних стосунків. Започаткована школами Кляйн та Малер терапевтична техніка, яка дістала назву «терапія грою» (play therapy) згодом виокремилася в самостійний напрям роботи $з$ дітьми. сеттінг.

Ключові слова: ігрова терапія, психоаналіз, дитячий психоаналіз, терапевтичний альянс,

Постановка проблеми. Розробка теоретичного підгрунтя та практики ігрової терапії пов'язана із поширенням психоаналітичного, гуманістичного та когнітивно-біхевіористичного напрямів психотерапії. У ході розвитку кожного напряму склалися власні традиції, засновані на спеціалізованій теорії та техніках, і водночас відбулося поглиблення та розширення теоретичних підходів, методів і технік.

Аналіз останніх досліджень. Аналіз наукових джерел засвідчує (Anderson, Edgcumbe, Васильєва, Парамонова та ін.), що в першій половині XX століття теорія і техніка дитячого психоаналізу перебувала на стадії розробки, а тому дослідники розвивали власні уявлення про 
психоаналітичну роботу з дітьми на основі спостережень та експериментів (Віннікот, Кляйн, ХугХельмут, Фрейд та ін.). Передусім у просторі психоаналізу та психодинамічної терапії відбулося накопичення емпіричних знань про ранній розвиток дітей. Учні та послідовники засновника психоаналізу звернулися до вивчення фактів з реального життя та клінічної практики, аналізу сновидінь і фантазій, історії розвитку власних дітей, дітей знайомих і друзів, спостерігали за поведінкою маленьких пацієнтів у ході проходження терапії та в повсякденному житті. Водночас еволюція дитячого психоаналізу та психодинамічної терапії виявилася складною та суперечливою.

Метою статі виступило дослідження особливостей становлення ігрової терапії в дитячому психоаналізі в традиціях шкіл Кляйн та Фрейд.

Виклад основного матеріалу дослідження. Досвід використання гри як допоміжного засобу увійшов в історію психоаналізу під назвою «випадок маленького Ганса». Хоча 3. Фрейд мало писав про дітей, однак в описах клінічних випадків звертався до інфантильних проявів у психіці дорослих як витоків їхніх невротичних конфліктів. У 1909 р. була опублікована робота Фрейда «Аналіз фобії п’ятирічного хлопчика» (відома як «випадок маленького Ганса»), що містила опис роботи 3 маленьким хлопчиком, який боявся коней. Терапія, а радше психоаналітичне спостереження за дитиною, проводилося батьком хлопчика, який проходив терапію в засновника психоаналізу і надавав йому свої звіти. Терапевтичне завдання полягало у вияві через ланцюг асоціацій і донесенні до свідомості дитини «істинного» джерела символічної гри. Представлений батьком хлопчика матеріал, у сучасному розумінні, був супервізуваний 3. Фрейдом, який пропонував рекомендації щодо подальшої роботи з сином. Однак в подальшому в ході розвитку теорії і практики психоаналізу фахівці відмовилися від психоаналітичної роботи 3 власними дітьми. Випадок маленького Ганса порівнюють також із сучасним варіантом напряму сімейної терапії.

Започаткування ігротерапії відбулося у 20-ті роки XX ст. у теоретичних пошуках та практиці роботи психоаналітиків (Хуг-Хельмут, Кляйн, Фрейд та ін.). Перші спроби використання гри в психоаналізі дітей здійснені Герміною Хуг-Хельмут, яку уважають піонером цієї галузі. Зібрані нею дані широко обговорювалися на засіданнях Віденського психоаналітичного товариства, публікувалися в періодичних виданнях. У період з 1912 до 1921 року в міжнародному психоаналітичному журналі «Imago» під керівництвом Хуг-Хельмут існувала постійно діюча рубрика «Про природу дитячої психіки».

Іншим центром дитячого психоаналізу, крім Відня, був Берлін, де проживала Мелані Кляйн, яка застосувала «ігровий метод» в аналізі дітей. Однак у 1926 році Кляйн переїхала до Лондона, де й продовжила розробку досліджень теорії і практики аналізу дітей. На думку істориків психоаналізу, дослідження Хуг-Хельмут багато в чому випередили теоретичні доробки Фрейд і Кляйн, але були незаслужено забуті. Хоча у своїх доробках Хуг-Хельмут обгрунтовано відмінності дитячого психоаналізу від психоаналізу дорослих та визначено важливість гри як одного із методів дитячого психоаналізу, однак про «ігрову терапію» дослідниця не згадувала. Роботи Хуг-Хельмут у хронологічній послідовності передують роботам Фрейд і Кляйн, але в них не було концептуалізовано іï власний терапевтичний підхід. Водночас нею було започатковано медико-педагогічні консультації з проблем виховання, метою яких була гармонізація стосунків між батьками і дітьми.

Дитячий психоаналіз на цьому етапі ще розглядався фахівцями як додаток до дорослого психоаналізу. Спроби безпосереднього перенесення технік психоаналізу в роботу з дітьми виявилися невдалими через особливості дитячого віку, оскільки проблема полягала в неможливості використання ключового для психоаналізу методу вільних асоціацій. Пошуки інших шляхів призвели (Віннікот, Кляйн, Фрейд, Хуг-Хельмут та ін.) до ідеї використання дитячої гри як аналогу методу вільних асоціацій.

3'явилися експериментальні майданчики для досліджень і перші психоаналітичні інститути, було запроваджено навчання фахівців теорії та практики психоаналітичної роботи 3 дітьми та дорослими, правила проходження особистої психотерапії дитячих психоаналітиків. Фахівці обговорювали теоретичні і практичні питання, зокрема щодо: показань та протипоказань дитячого аналізу; організації та правил сеттінгу і аналітичної техніки роботи 3 дітьми й заборони на проведення психоаналізу власних дітей, дітей родичів і близьких знайомих; природу перенесення 
та опору в дитячій терапії, вимог до психоаналітика тощо. В основу концепції емоційних порушень були покладені теоретичні уявлення 3. Фрейда та його погляди про нормальний хід розвитку дитини у послідовності та взаємозв'язку етапів особистісного становлення. У практиці роботи дитячі психотерапевти звернулися до вивчення процесів, що відбувалися у внутрішньому світі дитини (тривога, конфлікти, сни і фантазії тощо) у ході взаємодії із зовнішніми факторами (об’єктні стосунки із значимими дорослими, особливості догляду і переживання фрустрацій тощо).

Дослідження та концептуальне обгрунтування теорії і практики дитячого психоаналізу було здійснено школами Фрейд і Кляйн в період між Першою і Другою світовими війнами. Хоча обидві дослідниці використовували гру в роботі з дітьми, однак вони перебували в постійній полеміці через розбіжності з питань дитячого аналізу та ігрових технік роботи. Незважаючи на те, що обидва підходи грунтувалися на принципах і засадах психоаналізу, доробки Кляйн і Фрейд започаткували дві самостійні психоаналітичні школи в галузі дитячої психотерапії та різні позиції щодо розуміння гри та іï використання в дитячій психотерапії. Відзначимо, що такий розподіл зберігається в дитячому психоаналізі та дитячій психодинамічній психотерапії й донині. Виникнення різних теоретичних підходів призвело до збагачення терапевтичних технік, а суперечності між школами Кляйн та Фрейд вдалося подолати завдяки здійсненню в межах провідних психоаналітичних центрів підготовки фахівців за цими напрямами.

Згідно підходу Фрейд, у дитячому психоаналізі надавали перевагу роботі з невротичними дітьми, однак Кляйн довела ефективність «ігрового аналізу» в роботі з будь-якими порушеннями і розладами дітей. Дослідження Кляйн довели особливу значущість впливу першого року життя на формування психопатології та подальший розвиток індивіда. Вона описала два головних способи взаємодії людини зі світом: параноїдно-шизоїдну і депресивну позиції, які формуються на ранніх етапах дитячого розвитку. Фрейд, як і іiі батько, зверталася до більш пізніх етапів розвитку індивіда (віку від 3 до 5 років) та визнавала значущість в особистісному становленні людини розв’язання універсального, притаманного для всіх людей, Едипового комплексу.

У 1928 році Фрейд почала застосовувати на сесіях гру та іграшки як засіб побудови стосунків 3 метою зацікавлення дітей та досягнення терапевтичного альянсу 3 ними. Використовувала гру для розвитку терапевтичного альянсу 3 дитиною, для діагностики та розуміння ii стосунків з реальним світом, а також як умову для катарсису. Дослідниця також радила залучати батьків до терапевтичних процедур. У ході розвитку терапевтичних стосунків Фрейд поступово зверталася до вербальної взаємодії з дітьми, аналізу їхніх сновидінь та фантазій.

Дослідниця не погоджувалася 3 цілковитим ототожненням гри 3 вільним асоціюванням в аналізі дорослих, оскільки ігрові дії не завжди є символічним вираженням несвідомого матеріалу, а можуть відображати й реальний досвід та враження дитини. Вона, як і інші неофрейдисти, визнвала значущість реального оточуючого середовища та характеру інтерперсональних стосунків у дитячому розвитку, а не зміну об'єктів задоволення потягів. Зверталася й до важливості налагодження емоційного контакту між дитиною і терапевтом. Зокрема, вона використовувала фокуси, які й донині визнаються дієвими засобами в подоланні психологічних захистів та опору, а також задля позитивного підкріплення в налагодженні стосунків (Фрай, Гілрой та ін.). Фрейд займалася дитячою грою за аналогією роботи зі сновидіннями дорослих, намагаючись знайти несвідому мотивацію у грі та дитячих малюнках.

Однією з перших Фрейд почала застосовувати ігротерапію в роботі з дітьми, які пережили бомбардування Лондона під час Другої світової війни (цей досвід описаний нею у книзі «Діти і війна»). Спільно з найближчою подругою і соратницею Дороті Барлінг у 1940 Фрейд організувала «Хемпстедский дитячий будинок», на базі якого проводилося психоаналітичне дослідження дітей. Саме тут А. Фрейд розвинула дитячий аналіз як самостійну галузь психоаналізу, а в 1952 була заснована Хемпстедська клініка і курси дитячої терапії під іiі керівництвом. На відміну від Фрейд, яка використовувала гру переважно для побудови стабільних позитивних стосунків між дитиною $\mathrm{i}$ терапевтом, Кляйн використовувала гру замість вербальної взаємодії як природний засіб вираження думок, афектів та переживань дітей. Застосовуючи гру в дитячому психоаналізі, Кляйн виходила 3 припущення, що вільні ігрові дії символічно виражають зміст психіки (несвідомі бажання і фантазії) і виступають аналогом вільних асоціацій як головного методу психоаналізу. На 
думку Кляйн, завдяки грі відбувається екстерналізація та пом'якшення внутрішніх конфліктів, позбавлення від переслідуючих внутрішніх станів. Ігровий простір і відносини між об'єктами в ньому розглядалися нею як презентація «внутрішнього світу».

У дитячій психотерапії керувалася фундаментальними положеннями психоаналітичної доктрини, зокрема: визнавала дослідження несвідомого провідним завданням психоаналітичної процедури; зверталася до інтерпретацій та аналізу трансферу (перенесення) та контрперенесення як засобів розв'язання цього завдання. Дослідниця вважала, що майже будь-яка ігрова дія дитини може мати певний символічний смисл, виражати конфлікти і витіснені потяги. Зауважувала, що у процесі гри терапевт вступає у специфічні стосунки з дитиною, діючи як пасивна фігура (lay figure), якій дитина передає певні ролі, відповідні їі реальним стосункам з іншими людьми або почуттям до них. Відтак, у ході психотерапії терапевт потрапляє у фокус конфліктів дитини, а його завдання полягає в доведенні цих конфліктів до свідомості дитини шляхом інтепретації символічного смислу дитячої гри. При цьому Кляйн зауважувала, що окремі символічні моменти гри не слід інтерпретувати у відриві від усього контексту ігрової поведінки дитини.

У ході сеансів Кляйн спостерігала за грою дитини та активно брала в ній участь, зрозумілою для дітей мовою давала вичерпні інтерпретації ігрових дій, подібно до інтерпретацій вільних асоціацій дорослих. Намагалася інтерпретувати елементи гри та відносини між об'єктами як психологічний зміст психіки, виходячи 3 символічних значень несвідомого матеріалу гри (вказувала на агресивність, любовні та сексуальні стосунки тощо). У ході своєї роботи дійшла висновку, що ігрові заняття найкраще проводити поза домашніми умовами дитини й уперше обгрунтувала вимоги до ігрового матеріалу та ігрової кімнати. По суті, це був новий сеттінг, що включав іграшки і реальні об'єкти.

При цьому Кляйн наголошувала на доцільності й виваженості інтерпретацій дитячої гри, які не можуть бути випадковими. На іiї думку, інтерпретації, які пов'язують вияв несвідомого 3 аналітичною ситуацією, можливі у випадках, коли один і той же психічний матеріал дитини виражається за допомогою різних версій та засобів (іграшок, води, малюнка тощо) та супроводжується зростанням тривоги, почуттям провини або репрезентаціями будь-яких психологічних захистів. Уважала, що перенесення більш повно і виражено може проявлятися у відносинах з ігровими предметами, ніж з психотерапевтом. Задля полегшення вираження фантазій, Кляйн пропонувала кожній дитині власний набір іграшок. Такі набори зберігалися окремо, в шухлядках із замком. Це створювало інтимні, довірливі стосунки між терапевтом і пацієнтом, оскільки кожна дитина знала, що це їі іграшки, про які знають тільки терапевт і вона сама. У практиці роботи переважно використовувала маленькі, прості, немеханічних іграшки, оскільки вони дозволяли дитині найбільш повно виражати широкий спектр фантазій і переживань, а ставлення до іграшок давало важливий матеріал для аналізу. Серед ігрових наборів були не тільки фігурки людей, але й іграшкові предмети, що дозволяли гратися в магазин, школу, лікарню тощо, а також фарби, папір, ножиці, склянки з водою.

Дослідження і практичний досвід Хуг-Хельмут, Кляйн, Фрейд започаткували дитячий психоаналіз та терапевтичну техніку, що дістала назву «терапія грою» (play therapy), яка згодом виокремилася в самостійний напрям роботи з дітьми. Отже, вивчення наукових джерел (Асанова, Васильєва, О’Коннор, Парамонова, Четик та ін.) дозволило виокремити особливості та завдання психотерапевтичного впливу у психоаналітичній ігровій терапії першої половини ХХ століття.

1. 3 позиції обох шкіл було обгрунтовано важливість встановлення в терапевтичних стосунках емоційно позитивного контакту між дитиною і дорослим, що дозволяло психотерапевту здійснювати інтерпретаційні функції задля трансляції дитині символічного значення гри (брати участь у дитячій грі і організовувати актуалізацію і програвання значимих для дитини конфліктів).

2. Гра розглядалася як простір взаємодії та побудови терапевтичних стосунків, що забезпечував можливості для катарсису як форми емоційного реагування, вільного вияву почуттів і емоцій дитини та їх вербалізації, що призводить до подолання негативних емоційних переживань і звільнення від них.

3. Звернення до інсайту як результату і механізму терапевтичного впливу, що забезпечував досягнення більш глибокого розуміння дитиною себе і своїх стосунків із значимими іншими, знайденого у процесі переходу несвідомого у фокус свідомості. При цьому, інсайт у дитячому віці 
здебільшого набуває невербального характеру та не потребує інтерпретації. Усвідомлення досягається дитиною спонтанно, супроводжуючись емоційною активацією та інтуїтивним переконанням в його правильності.

4. Дослідження (тестування) реальності як процесу адаптації дитини і апробації нею різних форм і способів міжособистісної взаємодії і стосунків.

5. Створення в терапевтичному сеттінгу особливої атмосфери особистісної безпеки і довір'я, що забезпечує становлення терапевтичного альянсу, послаблення тривожності дітей та стимулює їх до дослідження нових способів поведінки і спілкування.

6. Сублімація як механізм трансформації енергії примітивних сексуальних потягів до соціально схвалюваних цілей виступила у дитячому психоаналізі як найвища форма розв'язання труднощів в особистісному розвитку в дитячому віці.

У 60-90-ті роки минулого століття дослідження об'єктних стосунків та проблем прив'язаності (Боулбі, Ейнсворт), розробка теорії сепарації-індивідуації (Малер) спрямували розуміння природи розвитку неврозів та дитячої психопатології від едіпального до прегенітального полюсу та вивчення раннього віку, відбулося зміщення фокусу з вивчення інстинктивного життя до вивчення процесу розвитку об'єктних стосунків дітей із значущими людьми (Кляйн, Віннікотт, Шпіц, Стерн та ін.). Поряд з розвитком теорії дитячого психоаналізу також вдосконалювалася й техніка роботи з дітьми, відбувається інтеграція психоаналітичних ідей 3 іншими науковими напрямами (зокрема, з нейропсихологією).

Висновки і перспективи подальших розвідок. У результаті активних пошуків робота психоаналітиків $з$ дітьми зосередилася на використанні гри, спостереження та інтерпретацій. За подальший період розвитку дитяча психоаналітична психотерапія втілилася в самостійний напрям, який обіймає різні теоретичні школи і методи, з власними принципами і формами клінічної роботи. Зміни теорії і технік класичного психоаналізу, розпочаті Фрейд та Кляйн, призвели до розвитку різних теоретичних моделей, об'єднаних в загальному напрямі психодинамічної психотерапії. В доробках останнього десятиліття звернулися до вивчення: формування психопатології дитини та стосунків матері і немовляти; психічного резонансу несвідомого в дитячій і материнській психопатології; витоків дитячої психосоматики; розуміння ролі батька в розвитку дитини; трансгенераційної передачі сімейної психопатології. Важливим завданням подальших вітчизняних досліджень 3 психоаналізу виступає інтеграція західноєвропейських психоаналітичних теорій розвитку і концепцій вітчизняної психологічної школи.

\section{СПИСОК ПОСИЛАНЬ}

Асанова, И. К. (2006). Методы психоаналитической работы с детьми от Фрейда до настоящего времени. Зигмунд Фрейд - основатель новой научной парадигмы: психоанализ в теории и практике: Материаль Международной психоаналитической конференции (Т. 2, с. 209212). Москва: Психоаналитическое общество.

Васильева, Н. Л. (2018). Психоаналитическая психотерапия детей. Вестник СанктПетербургского университета. Психология и педагогика, 8, 1, 70-82.

Парамонова, А. А. (2012). Основные проблемы детского психоанализа (к 100 - летию становления детского психоанализа). Прикладная юридическая психология, 3, 107-115.

Edgcumbe, R. (2004). Anna Freud - child analyst. In L. Rodriguez (Ed.), Child analysis today (pp. 4559). London; N.Y.: Karnak.

Anderson, R. (2004). Developments in technique in Kleinian child psychoanalysis. In L. Rodriguez (Ed.), Child analysis today (pp. 15-29). London; N.Y.: Karnak.

\section{REFERENCES}

Asanova, I. K. (2006). Metody psikhoanaliticheskoy raboty s detmi ot Freyda do nastoyashchego vremeni [Methods of psychoanalytic work with children from Freud to now]. Zigmund Freyd-osnovatel novoy nauchnoy paradigmy: psikhoanaliz $v$ teorii $i$ praktike: Materialy Mezhdunarodnoy psikhoanaliticheskoy konferentsii (T. 2, s. 209-212). Moskva: Psikhoanaliticheskoye obshchestvo. [in Russian]. 
Vasilyeva, N. L. (2018). Psikhoanaliticheskaya psikhoterapiya detey [Psychoanalytic psychotherapy of children]. Vestnik Sankt-Peterburgskogo universiteta. Psikhologiya i pedagogika, 8, 1, 70-82. [in Russian].

Paramonova, A. A. (2012). Osnovnyye problemy detskogo psikhoanaliza (k 100 - letiyu stanovleniya detskogo psikhoanaliza) [The main problems of child psychoanalysis (on the 100th anniversary of the formation of child psychoanalysis)]. Prikladnaya yuridicheskaya psikhologiya, 3, 107-115. [in Russian].

Edgcumbe, R. (2004). Anna Freud - child analyst. In L. Rodriguez (Ed.), Child analysis today (pp. 4559). London; N.Y.: Karnak. [in English].

Anderson, R. (2004). Developments in technique in Kleinian child psychoanalysis. In L. Rodriguez (Ed.), Child analysis today (pp. 15-29). London; N.Y.: Karnak. [in English].

\title{
FORMATION OF PLAY THERAPY IN PSYCHOANALYTIC SCHOOLS A. FREUD AND M. KLEIN
}

Svitlana Lytvynenko

Professor of the Department of Practical Psychology and Psychotherapy

Rivne State Humanities University http://orcid.org/0000-0002-7736-2152

Vadim Yamnitsky

Professor of the Department of Practical Psychology and Psychotherapy

Rivne State Humanities University http://orcid.org/0000-0002-1741-1303 DOI https://doi.org/10.35619/prap_rv.vi14.161

\begin{abstract}
The article investigates the features of the origin of play therapy in pediatric psychoanalysis in the traditions of M. Klein and A. Freud schools. Despite the fact that both approaches were based on the principles and principles of psychoanalysis, M. Klein and A. Freud started two independent psychoanalytic schools in the field of pediatric psychotherapy and different positions on the understanding of play and its use in pediatric psychotherapy. According to the A. Freud's approach, it was preferred to work with neurotic children in child psychoanalysis, but Klein proved the effectiveness of "play analysis" in dealing with any disorders and disorders of children. The empirical material was the results of historical and psychological studies of the process of formation and development of psychoanalytic knowledge about the child and the theory and practice of child psychoanalysis in the first half of the twentieth century. It was investigated that in the first half of the twentieth century the theory and technique of child psychoanalysis were in the development stage, and therefore the researchers developed ideas about psychoanalytic work with children on the basis of their own observations and experiments. It has been found that the initiation of play therapy took place in the 1920s. in theoretical research and practice of psychoanalysts ( Hug-Helmut, Klein, Freud, etc.). The conceptual substantiation of the theory and practice of child psychoanalysis was made by the schools of A. Freud and M. Klein in the period between the First and Second World Wars. Although both researchers used the play working with children, they were in constant controversy because of differences in child analysis and play techniques.

It was found that in child psychoanalysis, a play was considered as the natural activity of children, which provided opportunities for expression, demonstration and testing in symbolic form through toys, play activities and roles of unconscious desires and fantasies, as well as peculiarities of object relations. Launched by the schools of Klein and Mahler, therapeutic technique, which was called "play therapy", subsequently became a separate line of work with children.
\end{abstract}

Keywords: play therapy, psychoanalysis, child psychoanalysis, therapeutic alliance, setting. 